\title{
Financial Market Revisited
}

\author{
Teuta Ismaili-Muharremi ${ }^{1}$ \\ ${ }^{1}$ Senior Statistician at Cental Bank of the Rebublic of Kosovo; PhD @ , at the Doctoral School-European \\ University of Tirana, Adress: Pristina, 10000, Kosovo
}

\begin{abstract}
This paper examines the basic architecture of financial markets, focusing on the behavior of the financial markets during recent global financial crisis. Following on basic concepts of the financial markets, the paper provides a review of literature on the role of regulatory authorities highlighting the active direct and indirect role of these authorities in the evolution of the financial markets. Revisiting the role of the regulatory authorities in financial markets, the paper concludes that no financial market can develop in the sustainable manner without an active role of this authorities and without an adequate level of the economic development. In this context, the paper highlights the need for reducing the asymmetry of information as a precondition for ensuring stable financial markets and economy as well.
\end{abstract}

Keywords: financial market revisited, financial services, regulatory authorities, financial crisis, Western Balkans.

\section{Introduction}

Although the economic theory did not encounter any specific definition of the currency crisis that is acceptable as universal definition. Whenever we think about currency crisis the first thing we recall is a massive escape of investors from the currency for which they fear will depreciate thus affecting that this devaluation to really happen at a more financial repressive dimension than usual. In such a situation currency loses its stability and confidence, and if there are no sufficient international reserves then this can result in serious financial crisis.

\section{Basic characteristics}

When crisis occurs we tend to go back to the basics. In this context, this paper tries to elaborate on basic characteristics of the financial market. As we know, the financial market is a market where trading of financial instruments is done and depending on the assets and instruments that are traded we define financial markets as stock markets, bond markets, the Foreign Exchange trading market, debt market, equity market, etc. Investopedia for instance defines a financial market as a place where sellers and buyers do trading in financial assets such as securities (treasury bills, bonds, financial derivatives, etc.), while primarily financial markets are defined typically based on the transparency and pricing rules, costs and commissions and market forces that determine the price of securities traded.

Financial markets can't be imagined without the involvement of the state and its relevant institutions and/or agencies. In fact, financial markets are recognized as a regulated markets and this shows, first the role of the state in their development and, secondly, the importance that these markets have on a country's economy.

In particular state demonstrates its role in the development of financial markets by providing: an adequate legal infrastructure, technological infrastructure, regulation and adequate supervision.

Certainly, states differ from each other in the provision of infrastructure and regulation as well as the quality and supervision of financial markets, but in general, the financial markets are characterized by a technology platform and approximately the same regulation and supervision, which in fact relates to the implementation of standards internationally agreed, such as for example in the field of financial regulation and supervision of the Basel standards.

Speaking about Basel standards, the Bank for International Settlements (BIS) and International Organization of Securities Commissions (IOSCO) set the key principles for financial market infrastructure and monitors the implementation of these standards. In addition, within the BIS there is a Foreign Exchange Working Group 
(FXWG), operating under the auspices of the Markets Committee, which is mandated to strengthen code of conduct standards and principles in foreign exchange markets.

Regarding to the architecture of financial market we start here briefly with the division of overall financial markets as debt markets and equity markets (stocks shared), and then follow on the distinction between the money market and capital market. In essence the last distinction is mainly determined by the maturity of financial assets, so maturities under a year fall under the money market, while those over one year belongs usually to the capital market.

There is also a division of the third financial market and that in the primary market (securities issued are sold to original buyers: investment banks guarantee the securities) and secondary market (securities issued previously purchased and sold by agents and traders).

As mentioned earlier it is the maturity that defines market instruments that apply to debt market, i.e. whether they belong to the money or capital market. Equity market is a part of the capital market too. Money market instruments relate to treasury bills that are usually of short-term maturities such as 3 to 6 months and 12 months and their primary goal is to finance a one year financing gap in the budget of the government.

Regarding the main functions of the financial markets they can be summarized as: borrowing and lending, determination of the price, information gathering and coordination, allocation of risk, liquidity, efficiency.

We attempt to characterize the way how financial market operates, considering the two different types of financial institutions participating in these markets and the various ways in which these markets are structured.

Institutions that put in motion the financial markets are as follows: brokers, dealers, investment banks, stock markets, commercial banks and other financial intermediaries.

Broker is an authorized market participant who trades for his own account, whereas a dealer is called an authorized participant in the market that trades for his own account and others.

Investment banks help in the sale of securities newly/initially issued initial (e.g., in initial public offerings) by engaging in a number of different activities. They advise on whether to issue corporate bonds or shares, and for issued bonds of special type's payments they provide schedules for these securities.

Exchange securities market is a particularly established and organized to face cash bids and offers for the securities of movable property, issued by share holdings by the state and other public entities.

Commercial banks and other financial intermediaries: unlike brokers and dealers, financial intermediaries typically hold assets as part of a portfolio investment rather than as an inventory for resale. In addition, financial intermediaries make profits by charging relatively high for the assets kept in their investment portfolio.

However, the key issue is how to make financial markets working for the consumers (Campbell et al, 2011).But, from the macroeconomic viewpoint, the modern financial markets are supposed to be a kind of 'lubricant' for overall development of every country's economy.

In this context, Petersen and Wiegelmann (2014) they claim that the breakdown of the financial markets in 2007 and the subsequent debt crisis in the EU has produced enormous mistrust in financial products and the monetary system. In addition, the same authors warn that due to the dominance of the interest for profit by shareholders and other stakeholders (micro level) there has been developed a network of financial connections at macro level that made them too big or too connected to fail. This structure of financial markets actually has enabled for individual failures to be paid at macro-level. Furthermore, these authors provide a good evidence of self-innovation that usually works in the financial markets in a kind of vicious circle style. In this context, authors elaborate on following recent numerical new financial products:

- $\quad$ single securitizations (e.g., asset-backed securities [abs])

- multiple securitizations (e.g., collateralized debt obligations [cdo])

- securitization-based derivatives (e.g., credit default swaps [cds])

- re-securitization and re-hypothecation.

As relates to recent EU debt crisis, Caminal (2011) elaborates what has been EU institutional reaction to the crisis and provide a clear picture about the advantages and disadvantages of new mechanisms established to avert this crisis, whereas Eernisse (2012) elaborates on the role of the G-20 in improving the international financial architecture and concludes that G-20 and Basel Committee on Banking Supervision have reacted 
promptly with introduction of new measures related to capital and liquidity requirements and overall getting on board the relevant stakeholders for adapting to the new financial market architecture in the world.

\section{Literature Review}

The literature review on the role of the state in financial markets shows that the volume of scientific studies and professional analysis is growing with the occurrence of regional and global crisis. In fact, it has become obvious that after every serious crisis in the financial markets, there will be a call for further regulation or abandonment of inappropriate regulation that has been found to be a cause of financial crisis.

Given the complexity of the products and the internationalization of markets, Barry (2009) highlights the irreplaceable role of state regulators in the development of financial markets. On the other hand, Benito (2011) notes that the recent crisis has shown that financial markets with reliable and transparent trade infrastructure are more resistant compared to other segments of the financial markets that lack basic infrastructure and primary. For this reason, the derivatives market was the focus of regulators because bilateral risk management was not functioning as it should because there was no sufficient transparency.

Subbarao (2011) rightly concludes that the global crisis of 2008 was mainly resulted from the lack of regulation. So while technical infrastructure is more advanced thanks to globalization, regulation of financial markets is lagging behind somewhat and this has fueled the recent global crisis. The same author also elaborates on the dilemma such as what is optimal level of financial sector development, and what cost should regulate financial markets as well as how to spread this cost at global level.

However, there have been authors who have alerted for possible crises as a result of the negligence of financial markets regulation. In fact, a decade before the global crisis, Picciotto and Haines (1999) warned about the possibility of short regulation of financial markets globally making thus such regulation inadequate to prevent the destabilizing effects of global finance in the world economy. Later, White (2011) by analyzing what happened in the financial markets of the US in the years 2007-2009 only confirms that no prudential regulation of all financial institutions crises can be repeated again.

Lloyd and Peat (2010) point out that the lack of transparency in price and inadequate risk management in the financial derivatives market of trillions that have made derivatives market seriously threat of global financial market and he calls for better regulation of this market. According to the same authors, this progression of regulation should result in the derivatives trading to the market with more standardized contracts, then to, a greater volume and transparency in price. All this will provide the asset investment managers to understand better the risks contained in these markets and have more liquid instruments within their portfolio.

Regarding the financial market in Europe, Di Giorgio et al (2000) have raised very early the need for a European system of financial supervision, a topic which has been updated in recent years, especially with the introduction of the financial crisis in the Eurozone countries.

Consequently, Zufferey (2011) rightly concluded that the distribution of authority among various supervisory agencies and tools for coordination of activities among them need to be reviewed. In particular, the author emphasized the need for the imposition of appropriate prudential requirements and adequate review of the role that central banks should be separated, so for a greater clarity on their role in development of financial markets. Statman (2009) highlight that experience teaches us that there is a tendency to dramatization and thus influence the legislature and executive government to move towards a kind of paternalism in regulation when we are frightened by the crisis and also towards a kind of liberalism in regulation when we are excited with the current positive financial markets. The same author warns that there is a danger of not only moving more in one or other direction, but also a danger of not to moving enough at all.

This raises the need for as concluded by Cole and Slade (1998) to find comprehensive assessment of standard models for reforming the financial sector. Obviously here the point is in being proactive in terms of infrastructure, legal and regulatory requirements and as noted byCerny (1994) technological changes remains a variable independent and such challenge countries that lag behind in terms of advancement of their infrastructure and supervision of financial markets.

Undoubtedly, the global financial crisis of 2007-2009 and the current crisis in the euro zone are the best example to explain the role of the state in financial markets. Alan Greenspan, appreciated as "guru" of economy and finance in the years 1980-90, accuses regulators to have "walk very far in the process of deregulation of 
financial markets" and not being able to "properly predict the effect of toxic real estate loans." As a summary, a more concrete lessons learned from the global financial crisis and the challenges for the financial industry and policymakers can be found in the study of Wehinger (2008) who analyzing the causes and the measures proposed by the financial industry, authorities and institutions for putting the standard, calls for strengthening the mechanisms against financial crisis and the global advancement of multilateral surveillance in order to ensure the financial system is more resistant, healthier and efficient.

The role of the state in financial markets is crucial and multifaceted. Countries differ from each other by the level of development of their financial markets not only as a result of the quality of the role of government in financial markets, but also as a result of the level of overall economic development of the countries concerned.

For example, the countries of the Western Balkans in particular Kosovo and Albania they still have simple financial markets. They consist mainly from the banking sector, other financial intermediaries and the market of government securities. In practice, there are times when the state has demonstrated its role in the development of financial markets, but because of the level of economic development and other factors of such a market is not operational. For example, in the case of Albania we have had a proactive state regarding establishment of Tirana Stock Exchange but the fact is that since the establishment of this financial market in Albania there are not yet any enterprise listed in the stock exchange. This certainly shows that the current level of economic development does not generate sufficient motivation for stakeholders to be listed in this kind of market- Stock Exchange. On the other hand, we have the case of Kosovo, where the state is late with its role to develop a segment of the financial market - the market of securities of government (money market), at a time when many years Kosovo has placed the majority of its financial assets abroad by investing in securities in the international financial markets. Otherwise, Kosovo has launched the market of government securities starting from January 2012.This project has demonstrated in practical ways that the role of the state in the development of this financial market always remains crucial. Thus, the state has provided the technological infrastructure (electronic platform for securities trading), has provided legal infrastructure (approved Regulations for the primary and secondary market) and has provided training for the primary actors. In this way state has played direct role in the development of this market, but there are many other areas where the state indirectly plays a role in the development of financial markets. Take for example the capital market as an important part of the financial market. Speaking about the Western Balkans, Nuhiu and Hoti (2011) gives this summary of the problems faced by these countries in the development of the capital market:

- Relatively low level of capitalization of securities market;

- Limited perspective for joint investments and private investments;

- Small Transaction volume which results in high transaction costs;

- The very low number of market participants (the main participants are governments and some large public companies, very few private companies);

- Information on the investment and borrowing is not as readily available in developed markets and relatively high cost;

- Basic information on investment opportunities and yields is imperfect;

- Diversification of the investment portfolio is relatively expensive;

- The presence of high informal economy.

From the examples mentioned and problems listed above it appears that the role of the state in the development of financial markets is multidimensional and fundamental. No financial market can grow and perform without an active role of the state directly and indirectly and without an adequate level of economic development. In fact, Stiglitz et al (1993) while analyzing the role of the state in financial markets identifies seven major failures in the financial markets that are the basis for state intervention:

- Monitoring as a public good (lack of adequate monitoring leads to mismanagement and impairment of financial assets);

- Externalities monitoring, selection and lending (if selection done weak or wrong in the case of lending again compromised the value of financial assets);

- Externalities of financial disorders (failure even just of one financial institution may have significant effects); 
- Incomplete markets and non-existent (for example in most countries of the equity markets are weak);

- Imperfect competition (a client that has a long record with a bank may be unknown to the other bank);

- Pareto inefficiency of competitive markets (the collection of information is one of the essential functions of the financial markets, exchange and transfer of risk is another issue, many risks remain uninsured because financial markets are not complete);

- Uninformed investors (associated with the level of financial education providers as well as users of financial products)

Griffith-Jonesconsider international financial stability and efficiency as a very important global public good, particularly when viewing it from the perspective of developing and emerging economies.

\section{Conclusion}

The reasons for the involvement of the state can be wrapped up in two key areas for regulation of financial markets:

- Aimed in increasing the information for investors, which essentially relates to the reduction of negative selection.

- Ensuring the soundness of financial intermediaries, all this in order to prevent from any financial panic respectively ensuring the stability of financial markets.

The most recent example of involvement for the reasons mentioned above is what we are seeing today in the European financial market. As a result of institutional intervention we have now separate agencies for the prevention from instability such as the European Board of systemic risks and the European Banking Authority (Sapir, 2011).

\section{References}

[1] Benito, J. (2011) The role of market infrastructure in OTC Derivatives markets, Journal of Securities Operations \& Custody, 4 (4), p.346 - 357

[2] BIS and ISOCO: Committee on Payment and Settlement Systems and Technical Committee of the International Organization of Securities Commissions (2012) Principles for financial market infrastructures.

[3] BIS Papers 62: Inaugural address by Dr Duvvuri Subbarao, Governor, Reserve Bank of India at the First CAFRAL-BIS international conference on "Financial sector regulation for growth, equity and Stability in the Post-Crisis World", Mumbai, 15 November, 2011.

[4] Caminal, R.O. (2011) The EU architecture to avert a sovereign debt crisis, OECD Journal Financial Market Trends, 2011(2).

[5] Campbell J.Y et al (2011) Making Financial Markets Work for Consumers (Digest Summary), Harvard Business Review, Vol. 89, No. 7/8: 47-5

[6] Cerny, Ph. G (1994). The Dynamics of Financial Globalization: Technology, market structure, and policy response, Policy Sciences, 27 (4), p319-342.

http://dx.doi.org/10.1007/BF01000063

[7] Cole, D. C and Slade, BF (1998) The Crisis and Financial Sector Reform, ASEAN Economic Bulletin, 15 (3), pp. 338 46.

http://dx.doi.org/10.1355/AE15-3I

[8] Di Giorgio et al (2000) Financial Market Regulation: The Case of Italy and a Proposal for the Euro Area, Wharton Financial Institutions Center Working Paper 00-24.

[9] Eernisse, A.C. (2012) Banking on cooperation: the role of the G-20 in improving the international financial architecture, Duke Journal of Comparative \& International Law, 22(239), pp. 239-266.

[10] Griffith-Jones, S., New Financial Architecture as a Global Public Good, Available at: https://www.ids.ac.uk/files/griffithj4.pdf

[11]Lloyd, A and Peat, N. (2010) Periodical Divining the Rules of Derivatives. Securities Industry News, 22 (2), p23-23.

[12] Nuhiu, R.A. and Hoti, HA (2011) Effects of the Capital Markets Development on Economic Growth of Western Balkan Countries. European Journal of Economics and Administrative Sciences Finance, Issue 43, p.88 - 98. 
[13]Petersen, G.H. and Wiegelmann, M.A. (2014) Financial Markets and the Global Debt Crisis: Toward a New Architecture for A More Reliable Financial Sector, Norteamerica, 9(1), pp.79-107.

http://dx.doi.org/10.1016/s1870-3550(14)70114-4

[14] Picciotto, S. and Haines, J. (1999), Regulating Global Financial Markets, Journal of Law and Society, 26 (3), p.351-368. http://dx.doi.org/10.1111/1467-6478.00129

[15] Sapir, A. (2011) Europe after the Crisis: less or more roles for nation states in money and finance? Oxford Review of Economic Policy, 27 (4), pp. 608-619

http://dx.doi.org/10.1093/oxrep/grr027

[16] Stiglitz et al (1993) The role of the state in financial markets, the World Bank Research Observer, Annual Conference on Development Economics Supplement.

[17] Statman, M (2009) Regulating Financial Markets: Protecting Us from Ourselves and Others, Financial Analysts Journal, 65 (3), p1-10.

http://dx.doi.org/10.2469/faj.v65.n3.1

[18]Zingales, L. (2004), The Costs and Benefits of Financial Market Regulation, Law Working Paper No.21 / 2004 , University of Chicago, NBER, CEPR and ECGI.

[19]Zufferey Jean-Baptiste (2011) Regulating Financial Markets in Times of Stress is a Fundamentally Human Undertaking, the European Company and Financial Law Review. 8 (2), p259-275.

[20] White, J.L. (2011) Preventing Bubbles: what role for financial regulation? Cato Journal, 31 (3), p.603-619. http://dx.doi.org/10.2139/ssrn.1836752

[21] Wehinger, G. (2008) Lessons from the Financial Market Turmoil: Challenges ahead for the Financial Industry and Policy Makers, OECD Financial Market Trends Journal, 2008 (2), p33-72 